\title{
FGFR Inhibitor ASP5878
}

National Cancer Institute

\section{Source}

National Cancer Institute. FGFR Inhibitor ASP5878. NCI Thesaurus. Code C122719.

An orally bioavailable inhibitor of the fibroblast growth factor receptor (FGFR), with potential antineoplastic activity. Upon oral administration, FGFR inhibitor ASP5878 binds to and inhibits FGFR, which results in the inhibition of FGFR-mediated signal transduction pathways. This inhibits proliferation in FGFR-overexpressing tumor cells. FGFR, a family of receptor tyrosine kinases upregulated in many tumor cell types, plays a key role in cellular proliferation and survival. 